\title{
16. PALYNOLOGICAL EVIDENCE FOR LATE CENOZOIC ARID CONDITIONS ALONG THE NAMIBIA COAST FROM HOLES 532 AND 530A, LEG 75, DEEP SEA DRILLING PROJECT ${ }^{1}$
}

\author{
Eduard M. van Zinderen Bakker, Sr., Institute for Environmental Sciences, University of the O.F.S., \\ Bloemfontein, South Africa
}

\begin{abstract}
Some samples from DSDP Holes 530A and 532 were analyzed for their fossil pollen content. The sites are located in the southeastern corner of the Angola Basin, about $200 \mathrm{~km}$ west of the present coastline.

Fossil pollen assemblages of Holocene to Miocene age were compared with present-day pollen deposition in the arid Namib sand sea. The strong resemblance of all the pollen spectra indicates that very arid conditions existed in the coastal region of Namibia in Quaternary and Pliocene times. These data are in agreement with the late Miocene origin of the coastal aridity and with the conception that upwelling of cold water was responsible for these desert conditions.
\end{abstract}

\section{INTRODUCTION}

The aridity along the Namibia coast is caused by the somewhat offshore trade winds which are responsible for the upwelling of cold water in the Benguela system. This wind pattern is sustained by the stable South Atlantic anticyclone, which is situated near the coast and causes persistent subsiding and diverging air movement. The center of this anticyclone shifts seasonally in meridional direction, its southern position being at about $30^{\prime} \mathrm{S}$ in summer (Schulze, 1972). The aridifying effect of the anticyclone and the Southeast Trade Winds is intensified during most of the year by anticyclonic conditions over the subcontinent. The wind system along the coast drags the surface water westward; it is then replaced by cold water from below. The upwelled water originates in the sub-Antarctic zone of the Atlantic, where cold water sinks away and moves northward (van Zinderen Bakker, 1975, 1976). This cold water is one of the components of the northward-moving South Atlantic Central Water which wells up along the Namibia coast from a depth of a few hundred meters. Where the Benguela current is aligned to the coast, the isotherms of the surface water show that the upwelling has a very irregular pattern. The cold upwelled water mixes with the water of the Benguela Current, which has an overall temperature of $10-14^{\circ} \mathrm{C}$, is rich in nutrients, and has a low dissolved oxygen content (Bornhold, 1973).

The low temperature of the offshore surface water lowers the evaporation considerably, causes condensation in the form of thick fog, and minimizes precipitation along the coast. The concept of the correlation between the aridity of the west coast of southern Africa and the history of the Antarctic ocean and continent was proposed by van Zinderen Bakker (1975) and later also suggested by Tankard and Rogers (1978). The at-

\footnotetext{
${ }^{1}$ Hay, W. W., Sibuet, J.-C., et al., Init. Repts. DSDP, 75: Washington (U.S. Govt. Printing Office).
}

tempt by the author was not entirely successful, as he concluded from the then available ocean paleotemperatures assessed by Shackleton and Kennett (1975) that the aridity of the Namibia coast originated in early Oligocene times. At that time temperatures of deep water in high southern latitudes were low, as in the present day. However, at that time the East Antarctic Ice Sheet was only of limited size and the cold water mass moving northward would have been too small to lower the temperatures of the Proto-Benguela Current to aridify the Namibia coast.

Siesser $(1978,1980)$ has shown that high productivity as a consequence of strong persistent upwelling in the Benguela system began in the early late Miocene. The upwelling coincided with cooler conditions in the southwestern Cape, as has been demonstrated by Coetzee (1978a and 1978b) and not by Deacon (as suggested by Hendey [1981, p. 74]). Coetzee showed that in late Miocene and early Pliocene times, the palm vegetation of the S.W. Cape was still in existence, although the climate was cooler. The present study was undertaken to assess the former vegetation pattern along the coast using pollen evidence from ocean sediment samples.

\section{METHODS}

The samples studied were provided by the Deep Sea Drilling Project (DSDP) from Holes 530A and 532 of Leg 75, located in the southeastern corner of the Angola basin, respectively at $19^{\circ} 11.26^{\prime} \mathrm{S}$, $9^{\circ} 23.15^{\prime} \mathrm{E}$ and $19^{\circ} 44.64^{\prime} \mathrm{S}, 10^{\circ} 31.13^{\prime} \mathrm{E}$, only $20 \mathrm{~km}$ north of the Walvis escarpment (Fig. 1). Most of the samples (10) were taken from the undisturbed cores of Hole 532, which were collected by hydraulic piston coring about $160 \mathrm{~km}$ west of Cape Frio in water $1331 \mathrm{~m}$ deep. Two samples are from Hole $530 \mathrm{~A}$, which is situated about $100 \mathrm{~km}$ further westward in much deeper water $(4629 \mathrm{~m})$. The age of the samples varies according to the log from Holocene to late Miocene times. It is unfortunate that several samples, especially of Miocene age, proved to be sterile.

The samples were first soaked in water, and the clayey material was then dispersed in sodium pyrophosphate. This was followed by routine treatment including warm $\mathrm{HCl}, 40 \% \mathrm{HF}$, mineral separation with $\mathrm{ZnCl}_{2}$ solution, and acetolysis. Some of the samples gave an extremely low yield, while pollen was often folded and sometimes corroded, making identification difficult. The results of the analyses are shown in Table 1. 


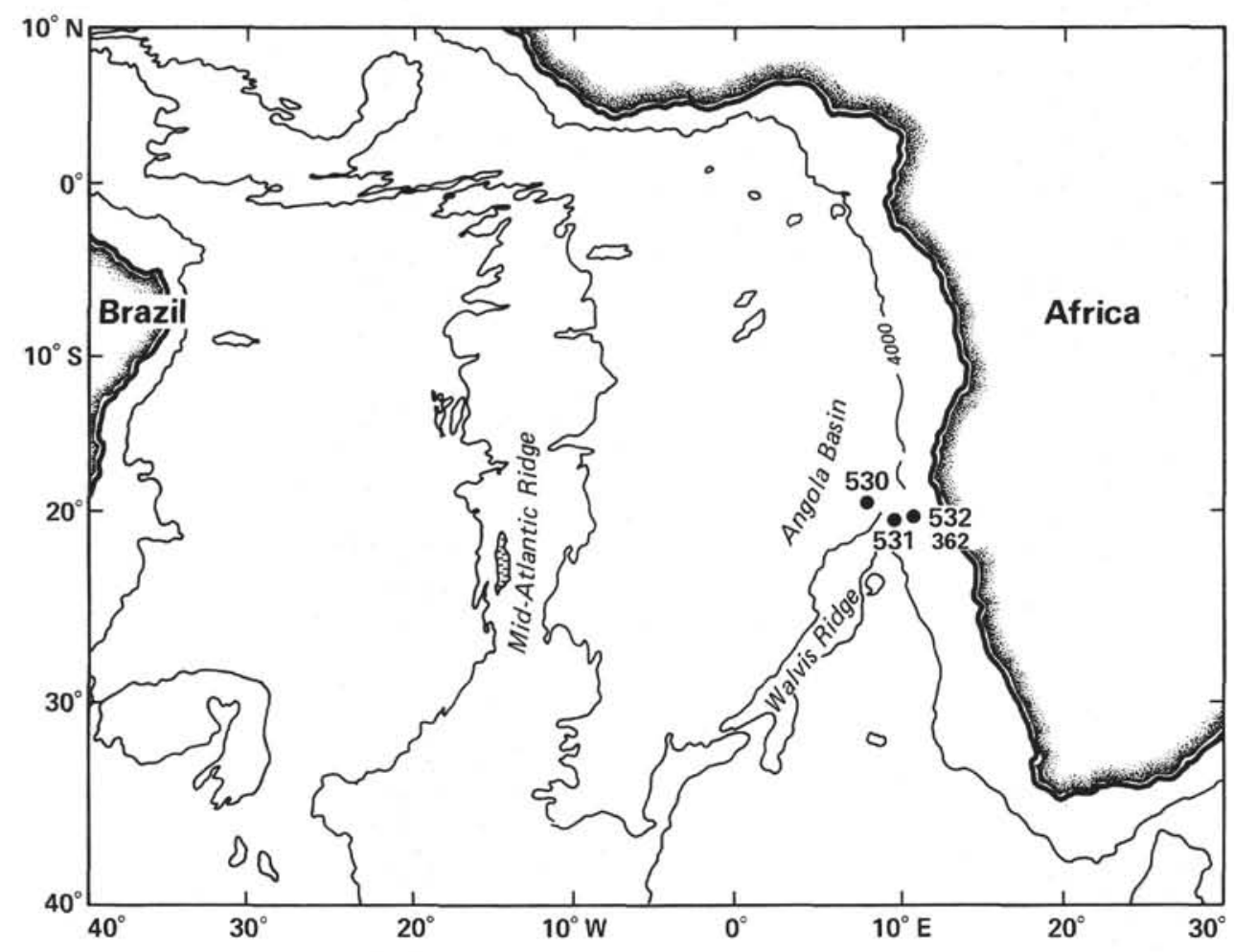

Figure 1. Site location map, Leg 75.

\section{RESULTS}

\section{Late Miocene}

Only one out of nine available samples contained pollen grains in sufficient numbers. Gramineae and Compositae pollen is represented in high percentages, while the Chenopodiaceae figure is the lowest of all the analyses $(1.1 \%)$.

\section{Early Pliocene}

Five samples were investigated and gave fairly good pollen counts (no. 8055, 8454, 8063, 8455, and 8456). According to the log of Hole 532, the early Pliocene core stretches from a depth of 142.6 to $246.8 \mathrm{~m}$, while the investigated early Pliocene samples from this site cover the depths of 151.6 to $243.8 \mathrm{~m}$.

The older pollen assemblages contain very high percentages of Gramineae pollen, while Chenopodiaceae reach a high maximum in a younger sample. The time span is characterized by the occurrence of low percentages of Acanthaceae, arboreal pollen, and palm pollen grains.

\section{Late Pliocene}

Of three samples from Hole 532 only two yielded sufficient pollen (no. 8451, 8452). The pollen spectra contain about equally high percentages of Chenopodiaceae and Gramineae and differ in this respect strongly from the early Pleistocene assemblages. A low number of palm pollen occurs.

\section{Early Pleistocene}

Three of the five samples from Hole 532 gave fairly good pollen counts (no. 8061, 8062, and 8450). These samples range in sub-bottom depth from 48.70 to 70.36 $\mathrm{m}$. The Pleistocene samples at the hole have, according to the log, a thickness of $70 \mathrm{~m}$ (sub-bottom depths of 4 to $74.4 \mathrm{~m}$ ). Gramineae predominate while the Chenopodiaceae show much lower percentages. Otherwise the pollen spectra are very similar to those of the late Pliocene.

\section{Holocene/Pleistocene}

One of the two samples from Hole 532 of this time span, no. 8447 , contained enough pollen to be counted. The equally high percentages of Chenopodiaceae and Compositae testify to arid conditions. The grass pollen is well represented and some arboreal pollen is present.

\section{Holocene}

A sample from Hole 532 (532-1-1, 50-57 cm), which according to the shipboard party was of Holocene age, gave anomalous results. Although much organic material was present the pollen yield was very low. The following sporomorpha show that the sediment contained reworked pollen of Cretaceous and Tertiary age: Classopollis, 4 grains, Tricolpites, sp., 1 grain, Ephedripites, 14 grains, cf. Echiperiporites, 1 grain, Sparganiaceaepollenites, 2 grains, Steevisipollenites, 1 grain.

Other finds were pollen of Combretum and palms and Gymnosperm xylem elements with bordered pits. 
Table 1. The pollen spectra of Sossus Vlei and DSDP samples in percentages.

\begin{tabular}{|c|c|c|c|c|c|c|c|c|c|c|c|c|c|}
\hline \multirow[b]{3}{*}{ Age } & \multirow{2}{*}{$\begin{array}{l}\text { Surface } \\
\text { sample } \\
\text { Sossus } \\
\end{array}$} & \multirow[b]{2}{*}{$\begin{array}{l}532-4-2, \\
50-56\end{array}$} & \multirow[b]{2}{*}{$\begin{array}{c}532-12-1 \\
70-77\end{array}$} & \multirow{2}{*}{$\begin{array}{l}532-12-2 \\
131-138\end{array}$} & \multicolumn{2}{|c|}{$\begin{array}{c}\text { Sample } \\
\text { (interval in } \mathrm{cm} \text { ) }\end{array}$} & \multirow[b]{2}{*}{$\begin{array}{l}532-23-2 \\
104-110\end{array}$} & \multirow[b]{2}{*}{$\begin{array}{l}530 \mathrm{~A}-4-4 \\
110-117\end{array}$} & \multirow[b]{2}{*}{$\begin{array}{l}532-37-1 \\
103-109\end{array}$} & \multirow[b]{2}{*}{$\begin{array}{c}532-44-3, \\
32-39\end{array}$} & \multirow[b]{2}{*}{$\begin{array}{c}532-51-1, \\
60-66\end{array}$} & \multirow[b]{2}{*}{$\begin{array}{l}532-60-1, \\
101-107\end{array}$} & \multirow[b]{2}{*}{$\begin{array}{l}530 \mathrm{~A}-10-2, \\
54-60\end{array}$} \\
\hline & & & & & $\begin{array}{c}532-17-1 \\
30-36\end{array}$ & $\begin{array}{c}532-19-2 \\
64-69\end{array}$ & & & & & & & \\
\hline & Recent & $\begin{array}{l}\text { Pleistocene/ } \\
\text { Holocene }\end{array}$ & $\begin{array}{c}\text { early } \\
\text { Pleistocene }\end{array}$ & $\begin{array}{c}\text { early } \\
\text { Pleistocene }\end{array}$ & $\begin{array}{c}\text { early } \\
\text { Pleistocene }\end{array}$ & $\begin{array}{c}\text { late } \\
\text { Pliocene }\end{array}$ & $\begin{array}{c}\text { late } \\
\text { Pliocene }\end{array}$ & $\begin{array}{l}\text { early } \\
\text { Pliocene }\end{array}$ & $\begin{array}{c}\text { early } \\
\text { Pliocene }\end{array}$ & $\begin{array}{c}\text { early } \\
\text { Pliocene }\end{array}$ & $\begin{array}{c}\text { early } \\
\text { Pliocene }\end{array}$ & $\begin{array}{c}\text { early } \\
\text { Pliocene }\end{array}$ & $\begin{array}{c}\text { late } \\
\text { Miocene }\end{array}$ \\
\hline Laboratory number & 8096 & 8447 & 8061 & 8062 & 8450 & 8451 & 8452 & 8055 & 8454 & 8063 & 8455 & 8456 & 8457 \\
\hline No. counted & 300 & 200 & 300 & 100 & 200 & 200 & 200 & 160 & 200 & 180 & 173 & 153 & 180 \\
\hline \multicolumn{14}{|l|}{ Non-arboreal pollen } \\
\hline Chenopodiaceae & 46.3 & 25.5 & 14.0 & 20.0 & 19.0 & 37.0 & 37.5 & 25.6 & 42.5 & 13.3 & 27.2 & 18.3 & 1.1 \\
\hline Gramineae & 15.0 & 33.0 & 61.7 & 45.0 & 51.0 & 37.0 & 29.0 & 33.7 & 24.0 & 52.7 & 40.5 & 41.2 & 51.7 \\
\hline Compositae & 10.0 & & 12.0 & & 16.5 & 15.0 & 17.5 & 16.2 & & 17.8 & 17.3 & 11.8 & 25.5 \\
\hline $\begin{array}{l}\text { Acanthosicyos } \\
\text { Justicia }\end{array}$ & $\begin{array}{l}9.7 \\
3.3\end{array}$ & & 1.0 & & 0.5 & & & & & & & & \\
\hline $\begin{array}{l}\text { Justicia } \\
\text { cf. Hypoestes }\end{array}$ & 0.7 & & 0.7 & & 0.5 & & & & & 0.5 & & & \\
\hline other Acanthaceae & 0.3 & & 0.3 & & & 1.0 & 2.0 & 0.6 & 1.0 & & 0.6 & 2.6 & \\
\hline Tribulus & 3.7 & 1.5 & 2.7 & 1.0 & 0.5 & 0.5 & 0.5 & & 0.5 & 0.5 & & & \\
\hline Cyperaceae & 1.0 & 3.5 & 3.0 & 3.0 & 3.0 & 2.5 & 1.0 & 0.6 & 2.0 & 2.8 & 0.6 & 5.2 & 1.7 \\
\hline Liliaceae & 3.0 & 1.5 & & & 0.5 & 0.5 & 1.0 & 1.2 & 4.0 & 1.1 & 0.6 & 9.1 & 3.9 \\
\hline Boraginaceae & 1.0 & & 0.5 & & & & 1.0 & & & & & & 1.1 \\
\hline Leguminosae & 0.3 & 1.0 & 0.3 & & & & 0.5 & & 2.0 & & & 1.3 & \\
\hline $\begin{array}{l}\text { ff. Geranium } \\
\text { Euphorbiaceae }\end{array}$ & $\begin{array}{l}0.3 \\
0.3\end{array}$ & & & & & & & & 1.0 & & & & \\
\hline Cruciferae & & & & & 0.5 & 0.5 & & 1.2 & & & 0.6 & & 0.6 \\
\hline $\begin{array}{l}\text { Ephedripites } \\
\text { Malvaceae }\end{array}$ & & & $\begin{array}{l}0.3 \\
0.3\end{array}$ & 1.0 & & & 1.0 & 0.6 & 2.0 & & 0.6 & 2.0 & \\
\hline $\begin{array}{l}\text { Malvaceae } \\
\text { Ericaceae }\end{array}$ & & & $\begin{array}{l}0.3 \\
0.7\end{array}$ & 1.0 & & & & 1.2 & & & & 0.7 & 0.6 \\
\hline Umbelliferae & & 0.5 & & & 0.5 & & & 1.2 & & & 0.6 & . & \\
\hline Typha & & & & & & & & 1.9 & & & & 0.7 & \\
\hline Aizoaceae & & & 0.3 & & & & & 0.6 & & & & & \\
\hline $\begin{array}{l}\text { Cardiospermum } \\
\text { Sparganicaeae- }\end{array}$ & & 0.5 & & & & & & & & & & & \\
\hline $\begin{array}{l}\text { Sparganicaeae- } \\
\text { pollenites }\end{array}$ & & & & & & & & 0.6 & & & 1.2 & & 0.6 \\
\hline $\begin{array}{l}\text { Restionaceae } \\
\text { Cycadaceae }\end{array}$ & & & & & & & 1.0 & & & & & & \\
\hline \multicolumn{14}{|l|}{ Arboreal pollen } \\
\hline $\begin{array}{l}\text { Combretaceae } \\
\text { Acacia }\end{array}$ & 0.7 & 0.5 & 0.3 & 0.1 & 0.5 & 0.5 & 1.0 & 2.5 & 1.0 & & & & \\
\hline $\begin{array}{l}\text { Acacia } \\
\text { Podocarpus }\end{array}$ & 2.3 & & & & & & & 1.9 & & & & & \\
\hline $\begin{array}{l}\text { Podocarpus } \\
\text { cf. Olea }\end{array}$ & & 1.5 & 0.7 & & & $\begin{array}{l}0.5 \\
0.5\end{array}$ & 0.5 & & 05 & & 0.6 & & \\
\hline $\begin{array}{l}\text { Celastraceac } \\
\text { Cola }\end{array}$ & & 1.3 & & & 0.5 & 0.5 & & & 0.5 & & 0.6 & & \\
\hline cf. Euclea & & & & & 0.5 & & 0.5 & & 0.5 & & & & 1.1 \\
\hline Anacardiaceae & & 0.5 & 0.3 & & & & & & 0.5 & 0.5 & & 0.7 & 0.6 \\
\hline Commiphora & & & 0.3 & 1.0 & & & & & & & & 0.7 & \\
\hline $\begin{array}{l}\text { Dichrostachys } \\
\text { Palmae }\end{array}$ & & & & & & & 3.0 & 0.6 & & 0.5 & 6.3 & 1.3 & \\
\hline Rubiaceae & & & & & & & & & 0.5 & & 0.0 & & \\
\hline Myrica & & & & & & & & & & & 1.2 & & 0.6 \\
\hline Spores & & 0.5 & & 1.0 & 0.5 & 0.5 & 0.5 & 3.1 & 0.5 & & & 1.3 & 1.1 \\
\hline Varia & 2.0 & 5.0 & 1.7 & 8.0 & 5.5 & 4.0 & 2.0 & 6.2 & 4.0 & 10.0 & 1.7 & 2.6 & 10.0 \\
\hline
\end{tabular}

This mixed assemblage cannot be the result of drilling disturbances but indicates redistribution of older sediments.

All the pollen spectra are marked by a very high percentages of Gramineae pollen, while Acanthaceae, Chenopodiaceae, Compositae, and Tribulus indicate aridity.

\section{DISCUSSION}

The fossil pollen spectra show a poor diversity in pollen types as can be expected in an arid to hyper-arid environment. The dominance alternates mainly between three sporomorpha, Gramineae, Chenopodiaceae and Compositae. The provenance of these pollen types is of great importance for the assessment of the paleoenvironmental changes which took place in the coastal region at present occupied by the Namib desert.

The lithology of the cores of Hole 532, as described by the shipboard party, shows that the sediments consist of open-marine pelagic deposits with variable amounts of terrigenous clay. As a consequence of the extremely high productivity of the pelagic zone, the organic carbon content of the sediments is $1-2 \%$ in the late Miocene, rises to a maximum of $3-6 \%$ in the late Pliocene, after which it declines slightly to $3-4 \%$ in the Pleistocene. There exists also a conspicuous fluctuation in light and dark sediments with a cyclic rhythm of $30,000-50,000$ yr. The nonbiogenic fraction of the dark layers is, according to the log, probably caused by an increase in wind-borne terrestrial clayey material.

These lithological details suggest that pollen occurring in the deposits of Hole 532 at a distance of $160 \mathrm{~km}$ off the coast of Kaokoveld cannot have been of fluviatile origin. The pollen must have been dispersed by wind which is at present blowing from the Namib desert in a NNW direction to the site.

The presence coastal desert can, according to Giess (1971), be divided into the following sections:

1) The northern Namib between the Kunene and the Huab Rivers (approximately between 17 and $21^{\circ} \mathrm{N}$ ). This section, which is situated on land opposite the boring sites, is partly $40 \mathrm{~km}$ wide. Typical plants are Acanthaceae (Barleria solitaria, Petalidium spp.) and Graminae. Grasses are fairly common even on the white sand dunes. 
2) The central Namib between the Huab and Kuiseb Rivers. Hummock dunes near the coast and wide gravel flats further inland bear a characteristic vegetation of Mesembryanthaceae, Zygophyllaceae, Amaranthaceae, and Chenopodiaceae. Annual white desert grasses are plentiful and grass plains also occur further inland. Acanthosicyos horrida forms small dunes in the river beds in the Northern and Central Namib, while Welwitschia mirabilis reaches its southern limit in the Central Namib.

3) The southern Namib is an area of 120 by $320 \mathrm{~km}$ between the Kuiseb River and $26^{\prime}$ S. In some rare years with more than usual rainfall, widespread desert grasses grow on the high dune slopes. The vegetation is very sparse except in the dry river bed where Acacia spp, are found.

4) The desert and succulent desert approximately between 26 'S and the Orange River. This winter rainfall area consists of barren desert plains and sand dunes in the west. In the eastern part, where more rain occurs, the stony hills and mountains harbor a rich vegetation of succulents and grasses.

These four sections of the Namib Desert all merge eastward into a wide grassland zone. According to Palgrave (1977) two indigenous palms, Hyphaena benguellensis and Phoenix reclinata, occur at present in Namibia far away from the coast. They are found in a wide zone along the northern border of Namibia and Zambia.

Some valuable data on the present pollen production of the coastal region is available for the evaluation of fossil pollen spectra. For the northern and central Namib, the analyses by Coetzee (1976) of river mouth sediments can be used. Information is available for the Kunene and the erratic flowing Hoarusib, Huab, and Swakop farther south. The pollen spectral of these four sediments contain the following pollen types (some average percentages are given in brackets. J. A. Coetzee, pers. comm.): Gramineae (63\%), Cyperaceae $(5.4 \%)$, Artemisia and other Compositae $(4.8 \%)$, Chenopodiaceae $(6.2 \%)$, and very low percentages of Acacia, Amarantaceae, Tribulus, Zygophyllum, Combretum, Colophospernum, Croton, Acanthaceae, and Celtis. The composition of these spectra shows a strong resemblance to the fossil spectra of Table 1 except for the dominance of Chenopodiaceae and Compositae in the fossil assemblages.

The pollen production of the present desert vegetation has also been studied farther south at Sossus Vlei (Table 1), a dry basin surrounded by very high dunes, situated in the southern Namib (Fig. 1). The sediments in this basin are laid down by the irregular flows of the Tsauchab River which originates in the Naukluft Mountains to the east. The part of the river bed upstream of Sossus Vlei is covered with small sand dunes, accumulating round cushions of Chenopodiaceae, and bushes of Acanthosicyos, an endemic Cucurbitaceae of the desert. Also growing along the river course are a number of Acacia trees. This explains the relatively high percentages of palynomorphs of these taxa in the surface sample no. 8096 (Table 1). The spectrum of Sossus Vlei also shows strong affinity to the fossil spectra when we take the local occurrence of many Chenopodiaceae, Acanthaceae, and Acanthosicyos in the Tchauchab valley into account.

Comparisons of the fossil pollen spectra with data on recent pollen production in the desert indicate arid to hyper-arid paleoenvironments during the Pliocene to Holocene in the coastal region.

Changes in sea level will in the past also have had an influence on the pollen production of the coastal region. During regressions wide sand-covered coastal plains must have been exposed to the strong wind associated with the regression phases. Eolian dunes with Gramineae and Cyperaceae separated by sebkhas full of Chenopodiaceae will have indicated hyper-arid conditions as during the late Pleistocene regression studied along the West African coast by Rossignol-Strick and Duzer (1979). These authors could separate the truly Saharan Chenopodiaceae (only 2-5\%) from the littoral Chenopodiaceous pollen which amounted to $50 \%$ during the regression. The grass pollen varied mostly between 30 and $40 \%$. Large percentages of Chenopodiaceae pollen have also been recorded during regressions along the Palestinian coast (Rossignol, 1969) and in the Argentine basin (Groot et al., 1967). Correlation of our fossil pollen spectra using Chenopodiaceae pollen counts is not feasible yet since the accurate age of the regression phases and of the pollen spectra is not known. The Chenopodiaceae percentage of the DSDP samples vary after the late Miocene between 13.3 and $42.5 \%$. The highest figures might well represent parts of the Messinian and the late Pliocene Regression (Vail and Hardenbol, 1979) as the river sediments only contain $6.2 \%$ of this pollen type.

\section{CONCLUSIONS}

The following inferences can tentatively be made from the pollen assemblages analyzed.

Late Miocene: The only pollen-containing sample could indicate that the sea level was comparatively high $(1.1 \%$ Chenopodiaceae) and that a dry, very open vegetation occupied the coastal region. During this time warm temperature to subtropical conditions with a vegetation of palms and Casuarina prevailed at the S.W. Cape (J. A. Coetzee, 1978 a, b). DSDP samples of terminal Miocene age have so far not been analyzed successfully.

Early Pliocene: The three oldest spectra represent a desert vegetation in which grasses dominated while Acanthaceae occurred. Comparatively low Chenopodiaceae figures could testify to a higher sea level. Sparse arboreal pollen in these and all the other fossil pollen samples show that tree growth was very limited.

Pollen of Palmae is found in late to very early Pliocene times (no. 8452-8456, except for no 8063). Some of this pollen is that of Hyphaene while a number of pollen grains belong to palm species which do not occur in Africa at present (Coetzee and Rogers, 1982).

This pollen shows that the palm vegetation which existed in the S.W. Cape in late Miocene times and persisted into the early Pliocene also continued to occur in very 
small numbers locally along the Namibia coast. The rich fossil fauna of Langebaanweg belongs to this transition period (Hendey, 1981) when the forest at the S.W. Cape opened up and the fynbos made its appearance in the early Pliocene (Coetzee, 1978b).

One sample (no. 8454) contains a very high percentage of Chenopodiaceae pollen $(42.5 \%)$ and could indicate a lower sea level. More varied tree growth points to different conditions farther inland.

Late Pliocene: The two samples show a change to perhaps colder and drier conditions with a possible lowering in sea level. These spectra show much resemblance to no. 8454. Some extinct palms still occurred.

Early Pleistocene: There exists a marked difference between the samples of early Pleistocene age and the spectra of numbers 8451,8452 , and 8454 . The three spectra of early Pleistocene age could point to a transgression. The climate was still dry. Conditions can be compared with those existing in the earliest Pliocene except for the occurrence of Palmae in that earlier period.

Holocene/Pleistocene: The only pollen spectrum available points to arid conditions; this can be concluded from the very high percentages of Compositae and Gramineae pollen and the near absence of arboreal pollen. The evidence, however, is slender and many more pollen data are required before definite conclusions can be drawn.

General: Although only few fossil pollen assemblages could be studied, all the results are in agreement and indicate that arid to hyper-arid conditions prevailed along the Namibia coast during Pliocene, Pleistocene, and Holocene times. No indications have been found for savannas or woodlands occurring in the coastal region. Some small variations in the composition of the fossil spectra point to small variations in temperature and humidity and possibly to sea level changes. The pollen of the typical dune plant Acanthosicyos horrida has not been found in the marine sediments. It is, however, very unlikely that the pollen of this insect-pollinated plant with a very local distribution would be transported by wind over very large distances as was the case with some grains of Podocarpus and Ericaceae.

The pollen evidence supports the view that the coastal desert existed during the period investigated and is in agreement with the results of Siesser $(1978,1980)$ on the age of the upwelling in the Benguela system.

It has recently been suggested that the Benguela upwelling could only reach its present extent during the late Pleistocene (Endrody-Younga, 1982) and that the Namib Desert is a "comparatively recent sand accumulation." According to this hypothesis the typical tenebrionid fauna of the sand dunes would have developed in isolated dune pockets which existed perhaps for millions of years in an otherwise not arid environment. The idea of an aridification very late in the Pleistocene does not agree with oceanographic and palynologic evidence.

\section{ACKNOWLEDGMENT}

I wish to thank DSDP for supplying the material. To my colleague Professor J. A. Coetzee I am indebted for fruitful discussions.

\section{REFERENCES}

Bornhold, B. D., 1973. Late Quaternary Sedimentation in the Eastern Angola Basin. Woods Hole Oceanographic Institution WHOI -7380. (Unpublished manuscript)

Coetzee, J. A., 1976. A report on a pollen analytical investigation of recent river mouth sediments on the southwest African coast. Palaeoecology of Africa, 9:131-135.

1978a. Climatic and biological changes in southwestern Africa during the Late Cainozoic. Palaeoecology of Africa, 10:13-29. 1978b. Late Cainozoic palaeoenvironments of Southern Africa. In van Zinderen Bakker, E. M. (Ed.), Antarctic Glacial History and World Palaeoenvironments: Rotterdam (Balkema), pp. 115-127.

Coetzee, J. A., and Rogers, J., 1982. Palynological and lithological evidence for the Miocene palaeoenvironment in the Saldanha Region (South Africa). Palaeogeogr., Palaeoclimatol., Palaeoecol., 39:71-85.

Endrody-Younga, S., 1982. The evidence of Coleoptera in dating the Namib Desert re-examined. Palaeoecology of Africa, 15.

Giess, W., 1971. A preliminary vegetation map of South West Africa, Dinteria, 4:1-114.

Groot, J. J., Groot, C. R., Ewing, M., Burckle, L., and Conolly, J. R., 1967. Spores, pollen, diatoms and provenance of the Argentine Basin sediments. Progress in Oceanography (Vol. 4): Oxford (Pergamon Press), 179-217.

Hendey, Q. B., 1981. Palaeoecology of the late Tertiary fossil occurrences in ' $E$ ' Quarry, Langebaanweg, South Africa, and a reinterpretation of their geological context. Ann. S. Afr. Mus., 84(1): 1-104.

Palgrave, K. C., 1977. Trees of Southern Africa: Cape Town (Struik).

Rossignol, M., 1969. Sedimentation palynologique dans le domaine marin quaternaire de Palestine: Etude de paléo-environement. Notes Mem. Moyen-Orient, 10.

Rossignol-Strick, M., and Duzer, D., 1979. West African vegetation and climate since 22,500 B.P. from deep-sea cores palynology. Pollen et Spores, 21(1-2):105-134.

Schulze, B. R., 1972. South Africa. In Griffin, J. F. (Ed.), Climates of Africa, World Survey of Climatology (Vol. 10): Amsterdam (Elsevier), 501-586.

Shackleton, N. J., and Kennett, J. P., 1975. Paleotemperature history of the Cenozoic and the initiation of Antarctic glaciation: Oxygen and carbon isotope analyses in DSDP Sites 279, 277, and 281. In Kennett, J. P., Houtz, R. E., et al., Init. Repts. DSDP, 29: Washington (U.S. Govt. Printing Office), 743-755.

Siesser, W. G., 1978. Aridification of the Namib Desert: Evidence from oceanic cores. In van Zinderen Bakker, E. M. (Ed.), Antarctic Glacial History and World Palaeoenvironments: Rotterdam (Balkema), pp. 105-113.

1980. Late Miocene origin of the Benguela Upwelling System off northern Namibia. Science, 208:283-285.

Tankard, A. J., and Rogers, J., 1978. Late Cenozoic palaeoenvironments on the west coast of Southern Africa. J. Biogeogr., 5: 319-337.

Vail, P. R., and Hardenbol, J., 1979. Sea-level changes during the Tertiary. Oceanus, 22:71-79.

Zinderen Bakker, Sr., E. M., van, 1975. The origin and paleoenvironment of the Namib Desert Biome. J. Biogeogr., 2, 65-73. 1976. The evolution of Late Quaternary palaeoclimates of Southern Africa. Palaeoecology of Africa, 9:160-202.

Date of Initial Receipt: September 21, 1982 


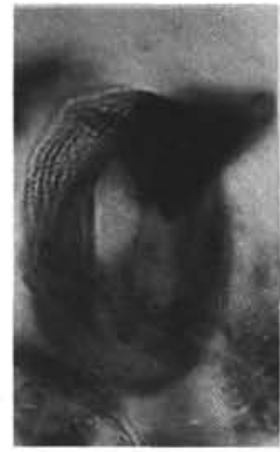

1

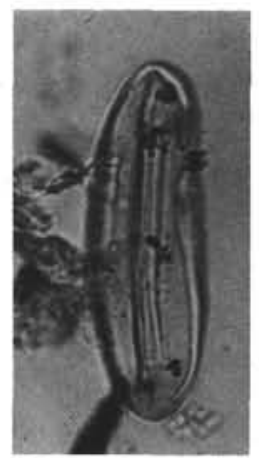

5

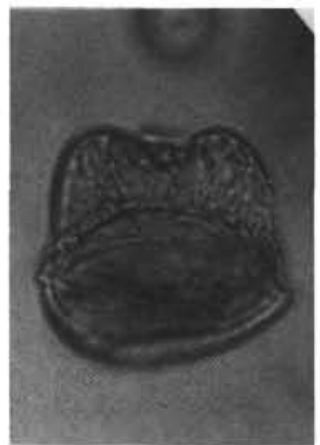

9

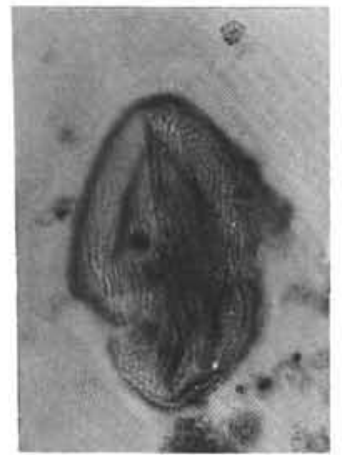

14

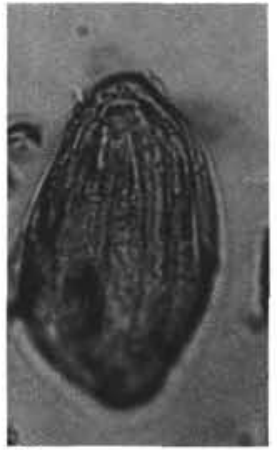

2

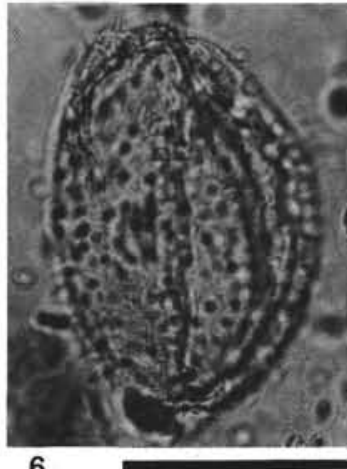

$25 \mu \mathrm{m}$

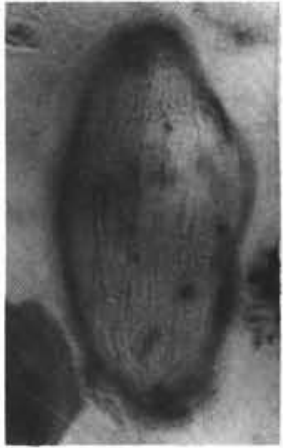

3A

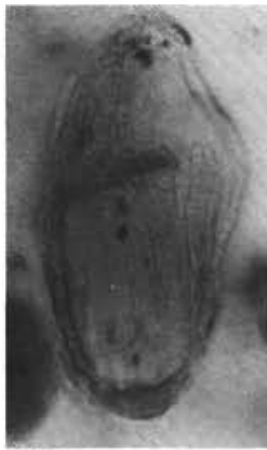

3B

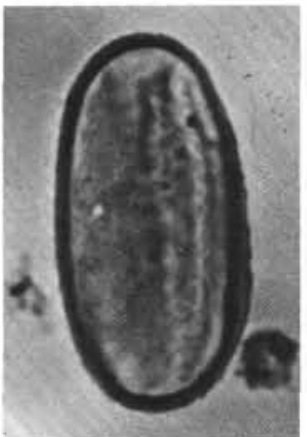

7
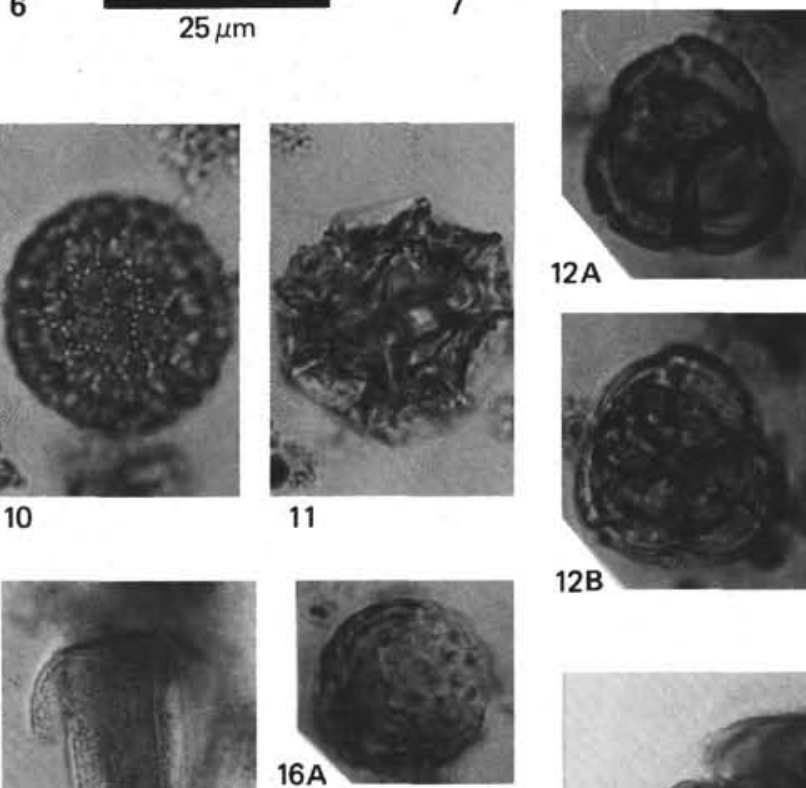

$16 \mathrm{~A}$

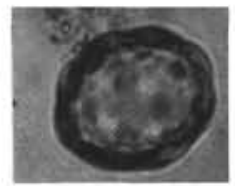

$16 \mathrm{~B}$

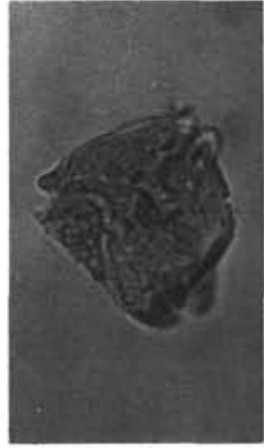

4

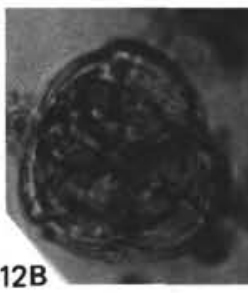

8A

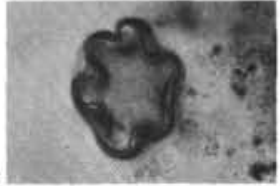

$8 B$
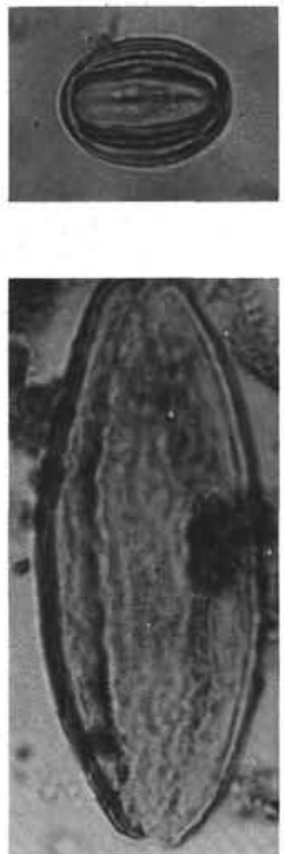

13

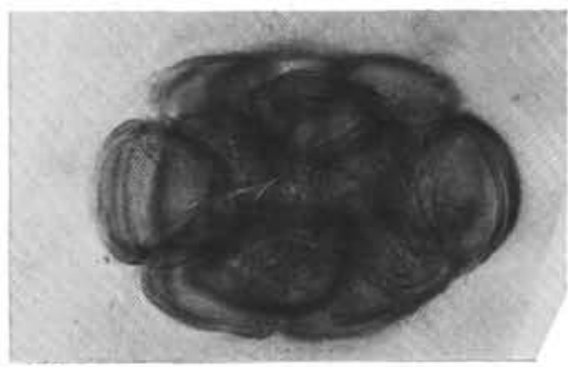

17

Plate 1. Fossil pollen, Leg 75. (All magnifications $\times 1000$.) 1-6. Recycled sporomorpha, Sample 532-1-1, 50-57 cm; (1) Classopollis, recycled; (2) Ephedripites sp., recycled; (3) Steevesipollenites sp., recycled, (A) high adjustment, (B) lower adjustment; (4) Tricolpites sp., recycled; (5) Palmae, recycled; (6) Palmae, recycled. 7, 8B-15. Pleistocene assemblages, Section 532-12-1; (7) Acanthaceae cf. Hypoestes sp., Pleistocene (70-77 cm). (8) Combretaceae; 8B, Pleistocene, equatorial view) $(70-77 \mathrm{~cm})$. (9) Podocarpus sp., Pleistocene (70-77 cm); (10) Tribulus sp., Pleistocene (70-77 cm); (11) Vernonieae, Pacourina type, Pleistocene (70-77 cm); (12) Ericaceae, Pleistocene (70-77 cm), (A) high adjustment, (B) lower adjustment; (13) Ephedripites sp., Pleistocene (131-138 cm); (14) Anacardiaceae, Pleistocene (70-77 cm); (15) Cyperaceae, Pleistocene (70-77 cm). 8A, 16-17. Pliocene pollen, Sample 530A-4-4, 110-117 cm; 8A, Combretaceae, polar view (16) Chenopodiaceae, Pliocene, (1) high adjustment, (B) lower adjustment; (17) Acacia sp., Pliocene. 